\title{
Monitoring the Influence of Sodium Chloride Particle Size on the Physical, Me- chanical Properties and Structure of Samples of Porous Aluminium Materials
}

\author{
Iva Nova, Karel Fraňa, Pavel Solfronk, David Korecek \\ Faculty of Mechanical Engineering, Technical university of Liberec, 1402/2, Czech Republic. E-mail: \\ iva.nova@tul.cz,karel. frana@tul.cz, pavel.solfronk@tul.cz, david.korecek@tul.cz.
}

The paper deals the production of porous aluminum materials that are characterized by lower density and mechanical properties. Samples of porous aluminium materials were produced on the basis of the developed methodology that applied sodium chloride particles of different sizes (average size 4, 6 and 9 $\mathrm{mm})$. The AlSi12 foundry alloy was preffered for the production of the aluminium porous material. As part of the experiments, samples of porous aluminium material in the shape of a truncated cone were made. The cavity of the foundry mould was in the shape of a truncated cone with diameters: $D=0.047$ $\mathrm{m}, \mathrm{d}=0.040 \mathrm{~m}$ and height $\mathrm{v}=0.040 \mathrm{~m}$. The material properties were determined on the produced samples. Their weight, volume and their density, relative density were calculated. Based on empirical relations, their value of Young's modulus of elasticity and value of thermal conductivity were determined. The compressive strength of selected samples was monitored as well. The value of Young's modulus of elasticity was determined from the measured stress-strain course. Furthemore, the porosity of the produced samples was evaluated on a scanning microscope.

Keywords: Porous aluminium materiuls, Sodium chloride, Relative density, Compressive strength, Young's tensile modulus.

\section{Introduction}

Currently the metallurgical industry focuses on the production of lightweight metal materials which must be also environmentally friendly. Lightweight metallic materials are referred to in the literature primarily as cellular metallic systems, most commonly referred to as "metallic" foams ". The idea of manufacturing metal cellular systems (metal foams) dates back to 1926 . Other sources state that the origin of cellular metal systems dates back to the 1940s DE MILLER [1]. HALBART [2], [3] states that there are four most commonly used basic types of "metal foam" production (direct melt foaming; controlled solidification of the melt in a supersaturated gas atmosphere; powder metallurgy; foundry methods).

Foundry methods can be divided into three basic groups; lost body casting, filling material casting [4] and replication process, $[4,5,6]$.

\section{Process of production of porous alumi- nium materials}

The first report on the replication process was issued in the early 1960s, and since then the development of the research group at the Swiss Federal Institute of Technology in Lausanne has evolved in various stages. Luna [6] publishes the whole process of this method in detail. This method is based on the use of vacuum which became to be a standard method for the production of "open cell metal foams" at the Department of Materials Engineering, University of Sheffield. At the same time, further research was carried out at this workplace and two other new methods called gas and mechanical infiltration were introduced. Metal cellular systems (porous metals and metal foams) are expanded metal materials that contain intentionally created pores in their structure that means aluminium porous materials, also referred to as "open-cell aluminium foams." These porous materials contain many free spaces called as pores or cavities in their structure. The size of the pores varies from a few nanometers to many millimetres and the size depends on the purpose of the porous material. In mechanical engineering, a homogeneous material is often preferred, but in the natural world the reverse effect occurs, which means that the pores have different sizes in the same structure, which is defined as the porosity gradation [8], [9], [10], [11] .

The characterization of the porous material depends on the pore size according to IUPAC (International Union of Pure and Applied Chemistry); ROQUEROL [12] and LIU [13] mention three classifications of microporous, mesoporous and macroporous materials) and particular definitions are given in publications [12], [13]. The macroporous material has a pore size greater than $50 \mathrm{~nm}$; it is commonly used for filters, anode material for fuel cells, stationary phases for various types of chromatography, bi- 
oreactors, microfluidic chips, filtering and heat transfer applications [15].

In foundry processes in the production of aluminium cellular materials, attention must be paid to their metallurgical preparation $[14,16]$. Open-cell metallic "foams", also referred to as porous metallic materials. These materials contain so-called open cells with adapted porous morphology based on particles of substances such as sodium chloride. These $\mathrm{NaCl}$ particles are filled with a melt of metal alloys, such as aluminium. By solidification of these metal melts, a heterogeneous system is formed consisting of metal and sodium chloride particles. Various technologies are used in the production of porous materials, [17], [18], [19], [20]. Other research preffered instead of sodium chloride particles of sand bound, for example, by furan resin or ceramic particles bound by gypsum. In all manufacturing methods, the mechanism by which the melt penetrates between the particles of the substance that define the cavities in the porous material is important. The most common method is infiltration of molten metal, also called the replication process [21].

Spherical granular urea as space holders was adopted for a production of porous materials based on powder metallurgy [22]. Another research work [23] focussed on corrosion effects for aluminium alloys, which are the basis of the production of porous materials. Our published work [24] deals with the monitoring of other possibilities for porous aluminium material production and the evaluation of their physical properties of such producced materials. The evaluation of the properties of porous materials was also dealt with by LUNA [6] and the most common physical quantities were found to be: the actual density, which is the density of the material without pores or cavities; bulk density is the density of the material, including open pores and cavities; pore volume is the addition of individual pore volumes; pore size is the distance between the walls of the pores, their width or diameter; porosity is the relationship between the total pore volume to the apparent volume of a sample or particle and the final surface area, which is the surface area of the non-porous material.

Within the use of sodium chloride for our research, knowledge about its properties published [25], on thermogravimetric (TG) and Differential Scanning Calorimetry analysis (DSC) was used. The melting point of sodium chloride at $802^{\circ} \mathrm{C}$ was confirmed, which is sufficient for the experiments of aluminium and sodium chloride alloys.

\section{Experimental production of aluminium porous materials}

Based on the above theoretical analysis, it is clear that the successful production of aluminium porous materials using sodium chloride must be based, for example, on the use of a vacuum system and inert gas (argon). Production of porous aluminium materials using sodium chloride particles (salt cores), resp. space holder particles (SHP) method is most often based on the melt infiltration process. Our experiments summarized below are based on the pressing of sodium chloride particles into the aluminium melt. For this purpose, an aluminium alloy (EN AC-44300) AlSi 12 (melting point approx. $577^{\circ} \mathrm{C}$ ) was used and the density is $2650\left[\mathrm{~kg} \cdot \mathrm{m}^{-3}\right.$. This method was used e.g. in publication [24] in which the production of porous aluminium material by pressing the melt between sodium chloride particles and evaluating the properties of the material produced was introduced. This publication presents the results of the production of an aluminium porous material by pressing sodium chloride particles into this melt. The chemical composition of used aluminium alloy AlSi12 was identified by a Bruker Q4 Tasman optical emission spectrometer - see Tab. 1 .

Tab. 1 Chemical composition of used AlSi12 aluminium alloy

\begin{tabular}{|c|c|c|c|c|c|c|c|c|c|c|}
\hline \multicolumn{1}{|c|}{ Chemical composition of aluminium alloy EN AC 44300 (AlSi12) [wt \%] } \\
\hline Si & Fe & $\mathrm{Mn}$ & $\mathrm{Cu}$ & $\mathrm{Zn}$ & $\mathrm{Ti}$ & $\mathrm{V}$ & $\mathrm{Mg}$ & $\mathrm{Na}$ & $\mathrm{Pb}$ & $\mathrm{Al}$ \\
\hline \multicolumn{8}{|c|}{ According to EN ČSN } \\
\hline $10.5-13.5$ & $0.45-0.90$ & 0.55 & 0.08 & 0.15 & 0.15 & - & - & - & - & - \\
\hline \multicolumn{10}{|c|}{ Real chemical composition of used alloy } \\
\hline 12.1 & 0.43 & 0.46 & 0.04 & 0.12 & 0.1 & 0.007 & 0.001 & 0.005 & 0.004 & 86.96 \\
\hline
\end{tabular}

A steel foundry mould (steel ČSN EN 1.2343) was used for the production of aluminium porous materials by pressing sodium chloride into an AlSi 12 aluminium alloy melt, see Fig. 1 (left). The cavity of the mould was in the shape of a truncated cone, as demonstrated in Fig. 1 ( right).

For the production of aluminium cellular system a combination of a foundry method using a filler material was addopted for the porous aluminium alloy. This material was sodium chloride of three sizes (see Fig. 2).: $4 \mathrm{~mm}$; $6 \mathrm{~mm}$ and $9 \mathrm{~mm}$ ( 3 to $5 \mathrm{~mm} ; 5$ to $7 \mathrm{~mm}$ and 8 to $10 \mathrm{~mm}$ ).

The cavity contained the half of the sodium chloride and half of the AlSi 12 alloy. Table 2 shows the calculated values of the weight of sodium chloride and AlSi 12 alloy 

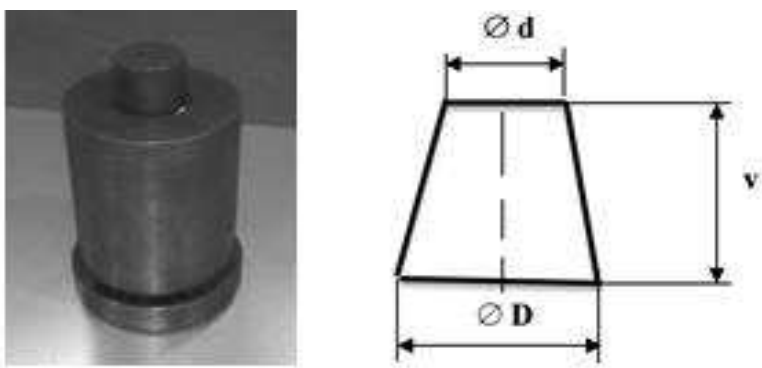

$\varnothing D=0,047 \mathrm{~m} ; \varnothing \mathrm{d}=0,040 \mathrm{~m} ; \mathrm{v}=0,040 \mathrm{~m}$

Fig. 1 Used foundry mould for the production of porous metals (on the left); schema of its cavity (on the right)
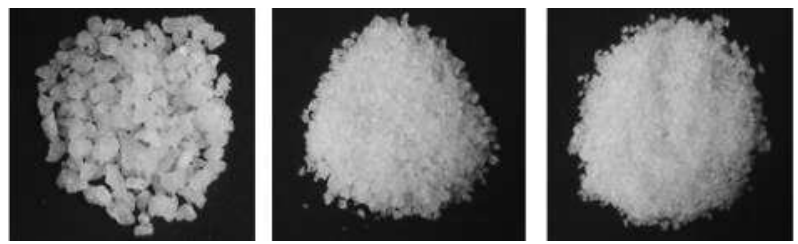

Fig. 2 Sodium chloride particle sizes for the production of aluminium porous materials (average salt particle size $9 \mathrm{~mm}, 6$ $\mathrm{mm}$ and $4 \mathrm{~mm}$ ).
The AlSi 12 alloy was melted in a graphite crucible in a "Classic" resistance melting furnace. The superheat temperature of the melt was varying between 720 and $750^{\circ} \mathrm{C}$. Before the onset of casting process into the foundry mould, the melt was metallurgically treated with refining salts. After measuring of the temperature, the melt was poured into the foundry mould. Prior to pouring the melt into the mould cavity, the mould was preheated to the operating temperature and treated with a protective graphite spray (Molybkombin UMF T4 spray). Then, a measured amount of the AlSi12 alloy melt was poured into the preheated foundry mould and finally, a measured amount of sodium chloride was poured into the mould, see Fig. 3 (left and middle). This mould containing the melt and sodium chloride was placed under a hydraulic press. The sodium chloride was pressed into the aluminium alloy melt with a punch (see Fig. 3 right). To push the sodium chloride particles into the aluminium alloy melt, it is important that a pressure of approximately $80 \mathrm{MPa}$ is exerted on the sodium chloride. At the same time, it is necessary that the hydraulic press mus be setting for this particular pressure level.

Tab. 2 Calculated values weight of sodium chloride and AlSi12 alloy

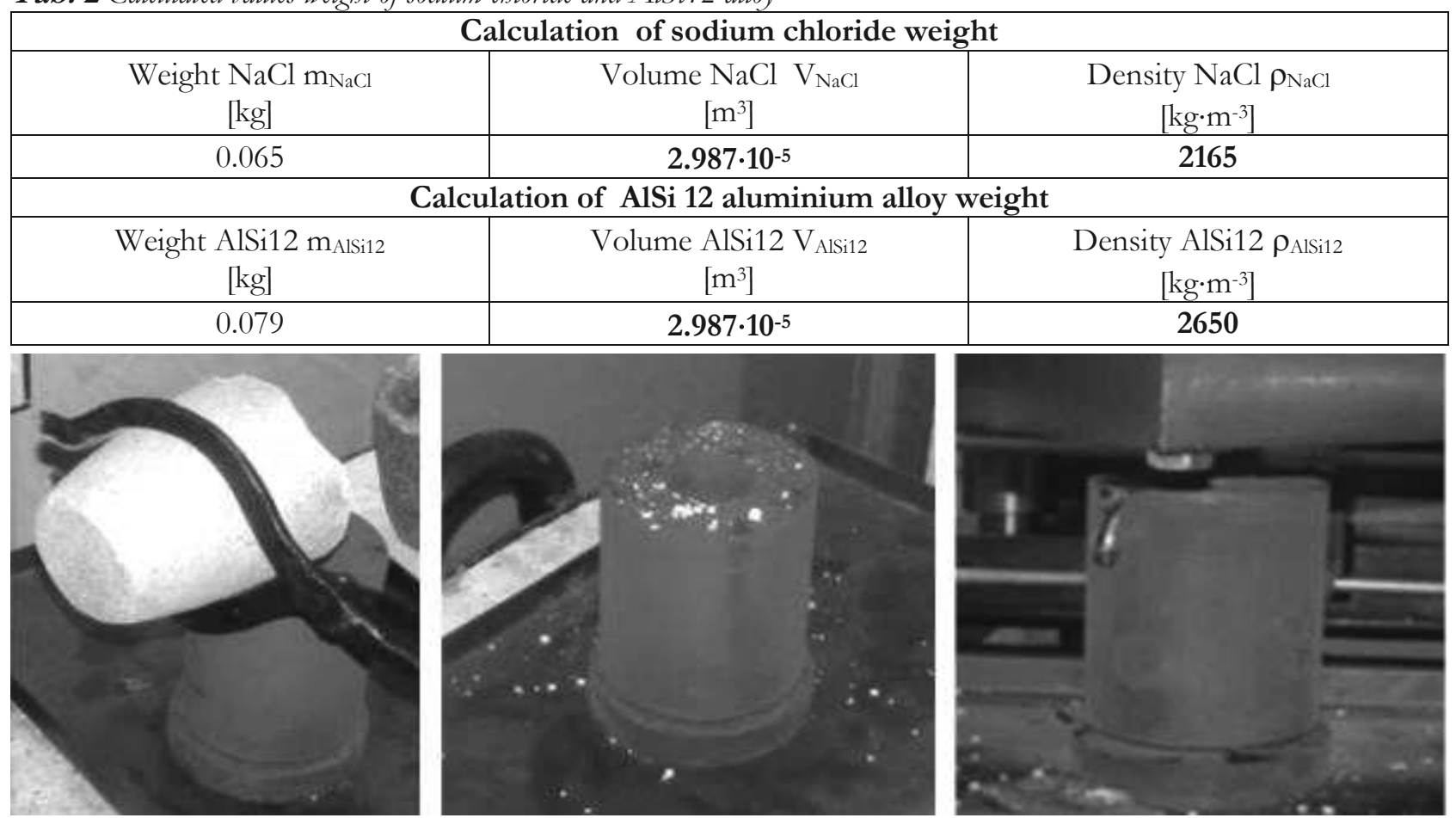

Fig. 3 Pouring the melt into the foundry mould, pouring NaCl into the mould and pressing NaCl into the AlSi 12 melt

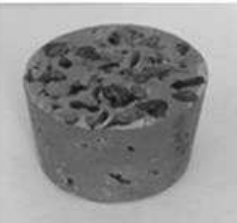

1

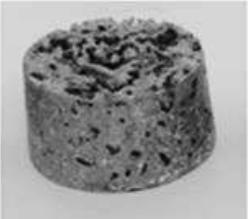

2

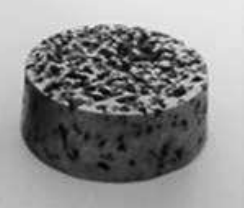

3
Fig. 4 Manufactured samples of porous aluminium materials from AlSi12 alloy in the shape of a truncated cone
In Figure 6 and 7, porous materials are produced using both types of sodium chloride particles by pressing them into an AlSi12 melt.

The produced samples of porous aluminium materials were analyzed, physical values were calculated on the basis of their material characteristics and particular values are given in Table 3 . 
Tab. 3 Basic dimensions and density of produced samples from aluminium porous material

\begin{tabular}{|c|c|c|c|c|c|c|c|}
\hline \multicolumn{8}{|c|}{ Basic dimensions and density of produced samples from aluminum porous material } \\
\hline \multirow[b]{2}{*}{$\begin{array}{c}\text { Sample } \\
\text { identification }\end{array}$} & \multirow[b]{2}{*}{$\begin{array}{c}\text { Size } \\
\text { particles } \\
\mathrm{NaCl} \\
{[\mathrm{mm}]}\end{array}$} & \multicolumn{3}{|c|}{ Basic dimensionlas of the sample } & \multicolumn{3}{|c|}{$V$ alues for density calculation } \\
\hline & & $\begin{array}{c}\text { Diameter } \\
\text { D } \\
{[\mathrm{mm}]}\end{array}$ & $\begin{array}{c}\text { Diameter } \\
\mathrm{d} \\
{[\mathrm{mm}]}\end{array}$ & $\begin{array}{c}\text { Height } \\
\text { h } \\
{[\mathrm{mm}]}\end{array}$ & $\begin{array}{c}\text { Mass } \\
\text { sample } \\
\mathrm{m} \\
{[\mathrm{kg}]}\end{array}$ & $\begin{array}{c}\text { Volume } \\
\text { sample } \\
\mathrm{V} \\
{\left[\mathrm{m}^{3}\right]}\end{array}$ & $\begin{array}{c}\text { Sample } \\
\text { density } \rho \\
{\left[\mathrm{kg} \cdot \mathrm{m}^{-3}\right]}\end{array}$ \\
\hline 1 & 8 to10 & 45.5 & 41.2 & 26.8 & 0.0379 & $4.057 \cdot 10^{-5}$ & 934 \\
\hline 2 & 5 to 7 & 46.5 & 42.3 & 25.0 & 0.0385 & $3.872 \cdot 10^{-5}$ & 994 \\
\hline 3 & 3 to 5 & 46.0 & 44.1 & 20.45 & 0.0354 & $3.258 \cdot 10^{-5}$ & 1086 \\
\hline
\end{tabular}

3.1 Evaluation of the properties of a porous material made of aluminum alloy AlSi12 produced by pressing $\mathrm{NaCl}$ into a melt of aluminum alloy

To evaluate the properties of the produced porous aluminium materials, we developed a methodology which was published [24]. This methodology is primary used for determining of the relevant physical and material characteristics, respectively relevant quantities. The evaluation of the produced aluminium porous materials concerns the determination of the following quantities:

Determination the density of the porous AlSi12 alloy ( $\left.\boldsymbol{\rho}_{\text {P.Alsi12 }}\right)$ - it is determined by physical calculation according to the following relation:

$$
\rho_{P .(\text { AlSi12) }}=\frac{m_{P .(\text { AlSi12 })}}{V_{P .(\text { AlSi12 })}},
$$

Where:

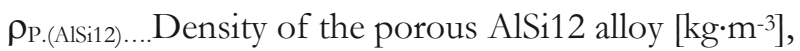
mP.(AlSi12)... Weight of the porous AlSi12 alloy [kg],

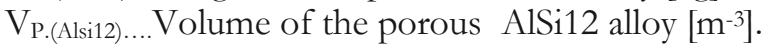

\section{Determination the relative density of the porous}

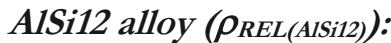

$$
\rho_{R E L(A l S i 12)}=\frac{\rho_{P .(A l S i 12)}}{\rho_{B .(A l S i 12)}}
$$

Where:

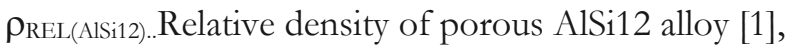
$\rho_{\mathrm{P}(\mathrm{AlSi12})}$.....Density of porous AlSi12 alloy $\left[\mathrm{kg} \cdot \mathrm{m}^{-3}\right]$,

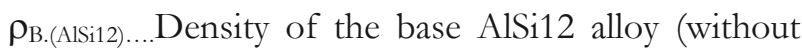
porosity) $\left[\mathrm{kg} \cdot \mathrm{m}^{-3}\right]$.

\section{Determination the density of discretized structure of the porous AlSi12:}

$$
\rho_{P(A l S i 12)}=\frac{\rho_{B .(A l S i 12)} \cdot V_{P .(A l S i 12)}}{V_{B .(A l S i 12)}},
$$

here:

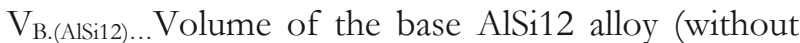
porosity) material $\left[\mathrm{m}^{3}\right]$.

\section{Determination the porosity of porous AlSi12 alloy (Por $\varepsilon):$}

It is the ratio of density difference between base AlSi12 alloy and porous AlSi12 (porous AlSi12 P.(AlSi12)) to density of base (non-porous) AlSi12 (B.(AlSi12)):

$$
P=\left(1-\frac{\rho_{P .(\text { AlSi12 })}}{\rho_{B .(\text { AlSi12 })}}\right) \cdot 100[\%]
$$

Determination the Young's modulus of elasticity in porous AlSi12, determined by [14]:

$$
E_{P .(\text { AlSi12) }}=\boldsymbol{k} \cdot E_{B .(\text { AlSi12 })} \cdot\left(\frac{\rho_{P .(\text { AlSi12 }) .}}{\rho_{B .(\text { AlSi12 })}}\right)^{m}
$$

Where:

EP.(AISi12)....Young's modulus of elasticity of porous AlSi12 alloy [MPa],

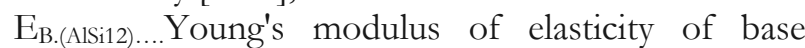
AlSi12 alloy [MPa],

$\rho_{\mathrm{B}(\mathrm{AlSi} 12)}$.... Density of the base material $\left[\mathrm{kg} \cdot \mathrm{m}^{-3}\right]$,

$\mathrm{k}$.....Constant for calculation of the modulus of elasticity $\mathrm{k}=(0,1$ to 4$),[14]$,

m...Constant for calculation of the modulus of elasticity $\mathrm{m}=2$ [14], $\mathrm{m}=1.5$ to 1.7 [26].

Calculation of the coefficient of thermal conductivity of porous AlSi 12 alloy through a relationship [14]:

$$
\lambda_{A l . P .}=\lambda_{B . M \cdot}\left(\frac{\rho_{A l . P .}}{\rho_{B . M .}}\right)^{a}
$$

Where:

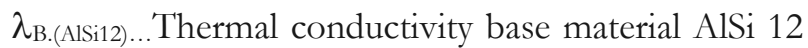
alloy $\left(\lambda_{\text {B.(AlSi12). }}=150 \mathrm{~W} \cdot \mathrm{m}^{-1} \cdot \mathrm{K}^{-1}\right]$, a.... Constant $(\mathrm{a}=1.65$ to 1.85$)$ [14], $\mathrm{a}=2$ [26].

Based on the equations from (1) to (6), the selected values of properties of the porous materials were calculated and values are shown in Table 4. 
Tab. 4 Values of aluminium alloy AlSi 12 porous material production squeeze $\mathrm{NaCl}$ into melt aluminium alloys

\begin{tabular}{|c|c|c|c|}
\hline \multicolumn{4}{|c|}{ Properties of samples: $1,2,3$} \\
\hline Sample numbers & 1 & 2 & 3 \\
\hline Average particle size sodium chloride $[\mathrm{mm}]$ & 8 to10 & 5 to 7 & 3 to 5 \\
\hline $\begin{array}{l}\text { Density of sample from AlSi 12, (base material) } \rho_{\mathrm{B} .(\mathrm{AlSi} i 2)} \\
\qquad\left[\mathrm{kg} \cdot \mathrm{m}^{3}\right]\end{array}$ & 2650 & 2650 & 2650 \\
\hline $\begin{array}{l}\text { Volume of sample AlSi 12, (base material), } \mathbf{V}_{\text {B.(AIsi12) }}\left[\mathrm{m}^{3}\right] \\
\qquad \mathrm{D}=45.5 \mathrm{~mm} ; \mathrm{d}=41.2 \mathrm{~mm} ; \mathrm{h}=26.8 \mathrm{~mm} \text {; sample } 1 ; \\
D=46.5 \mathrm{~mm} ; \mathrm{d}=42.3 \mathrm{~mm} ; \mathrm{h}=25.0 \mathrm{~mm} \text { sample } 2 \\
\mathrm{D}=46.0 \mathrm{~mm} ; \mathrm{d}=44.1 \mathrm{~mm} ; \mathrm{h}=20.45 \mathrm{~mm} \text {; sample } 3\end{array}$ & $4.057 \cdot 10^{-5}$ & $3.872 \cdot 10^{-5}$ & $3.258 \cdot 10^{-5}$ \\
\hline $\begin{array}{c}\text { Weight of sample AlSi 12, } \mathbf{m}_{\mathrm{B} .(\mathrm{AlSi} 12)}[\mathbf{k g}] \\
\mathrm{D}=45.5 \mathrm{~mm} ; \mathrm{d}=41.2 \mathrm{~mm} ; \mathrm{h}=26.8 \mathrm{~mm} \text {; sample } 1 ; \\
\mathrm{D}=46.5 \mathrm{~mm} ; \mathrm{d}=42.3 \mathrm{~mm} ; \mathrm{h}=25.0 \mathrm{~mm} \text { sample } 2 \\
\mathrm{D}=46.0 \mathrm{~mm} ; \mathrm{d}=44.1 \mathrm{~mm} ; \mathrm{h}=20.45 \mathrm{~mm} \text {; sample } 3\end{array}$ & 0.108 & 0.103 & 0.0863 \\
\hline Volume of sample of AlSi12 porous; $V_{P .(A l S i 12)}\left[\mathrm{m}^{3}\right]$ & $4.057 \cdot 10^{-5}$ & $3.872 \cdot 10^{-5}$ & $3.258 \cdot 10^{-5}$ \\
\hline Weight of sample AlSi 12 porous; $\mathrm{W}_{\text {P.(AlSi12) }}[\mathrm{kg}]$ & 0.0380 & 0.0385 & 0.0354 \\
\hline Density of sample AlSi12 porous; $\rho_{\text {P.(AlSi12) }}\left[\mathrm{kg} \cdot \mathrm{m}^{3}\right]$ & 947 & 994 & 1086 \\
\hline Relative density of AlSi 12 (porous/base); $\rho_{\text {REL(AlSi12) }}[1]$ & 0.36 & 0.38 & 0.41 \\
\hline Porosity of AlSi 12 (porous AlSi12 alloy) P [\%] & 64 & 62 & 59 \\
\hline $\begin{array}{l}\text { Young's tensile modulus of elasticity AlSi } 12 \text { (porous AlSi12 } \\
\text { alloy) } \mathbf{E}_{\text {P. AlSi12) }}[\mathbf{M P a}]\end{array}$ & 958 & 1055 & 1260 \\
\hline $\begin{array}{l}\text { Coefficient of thermal conductivity of AlSi } 12 \text { (porous AlSi12 } \\
\text { alloy) } \lambda_{\text {P.(AlSi2) }}\left[\mathbf{W} \cdot \mathbf{m}^{-1} \cdot \mathbf{K}^{-1}\right]\end{array}$ & 27 & 30 & 34 \\
\hline
\end{tabular}

Note: $E_{\text {B.M. (AlSi12) }}$ - Young's module of elasticity, $E_{\text {AlSit } 2}=75000[\mathrm{MPa}] ; k=0.1 ; m=2 ; a=1.65$

3.2 Monitoring the structure of samples of porous materials

The connection of open cells in the structure of the AlSi12 alloy of porous aluminum materials was observed using the electron scanning microscope (Vega 3 Tescan, SEM HV $20.0 \mathrm{kV}$ ). The samples 1, 2 and 3 in Fig. 5 were selected for the identification of their porosity in a plan view. Figures from 6 to 8 show typicall structures of the selected samples 1,2 and 3 in details, where the porosity were observed using an electron scanning microscope.
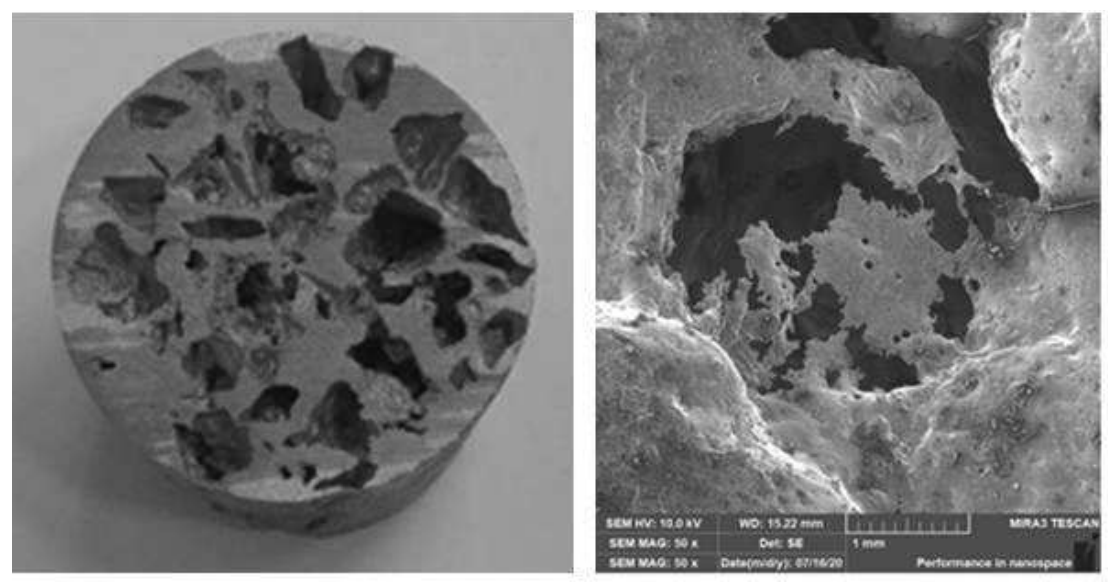

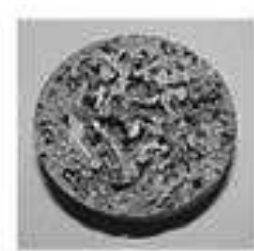

2

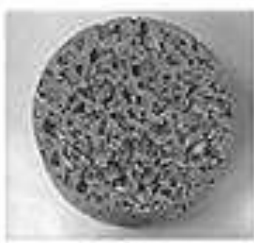

3
Fig. 5 View of samples for monitoring cells of porous materials made of AlSi12 alloy (samples, 1, 2 and 3)

Fig. 6 View of the structure of sample of porous material AlSi12 alloy, sample 1 

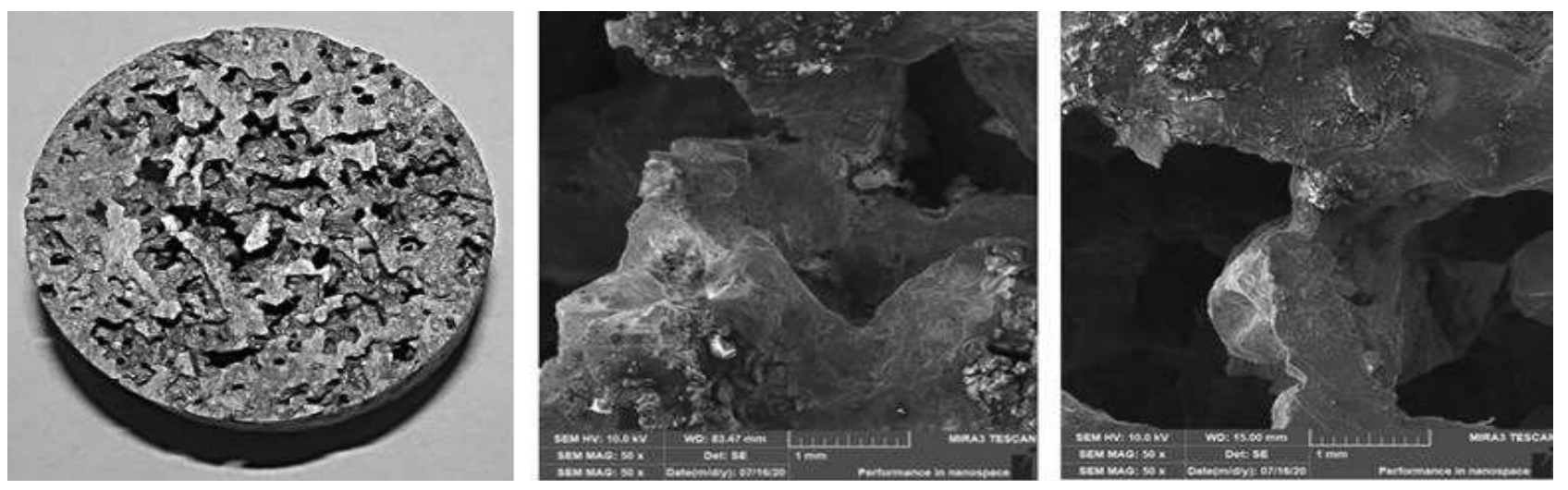

Fig. 7 View of the structure of sample porous material AlSi12 alloy, sample 2
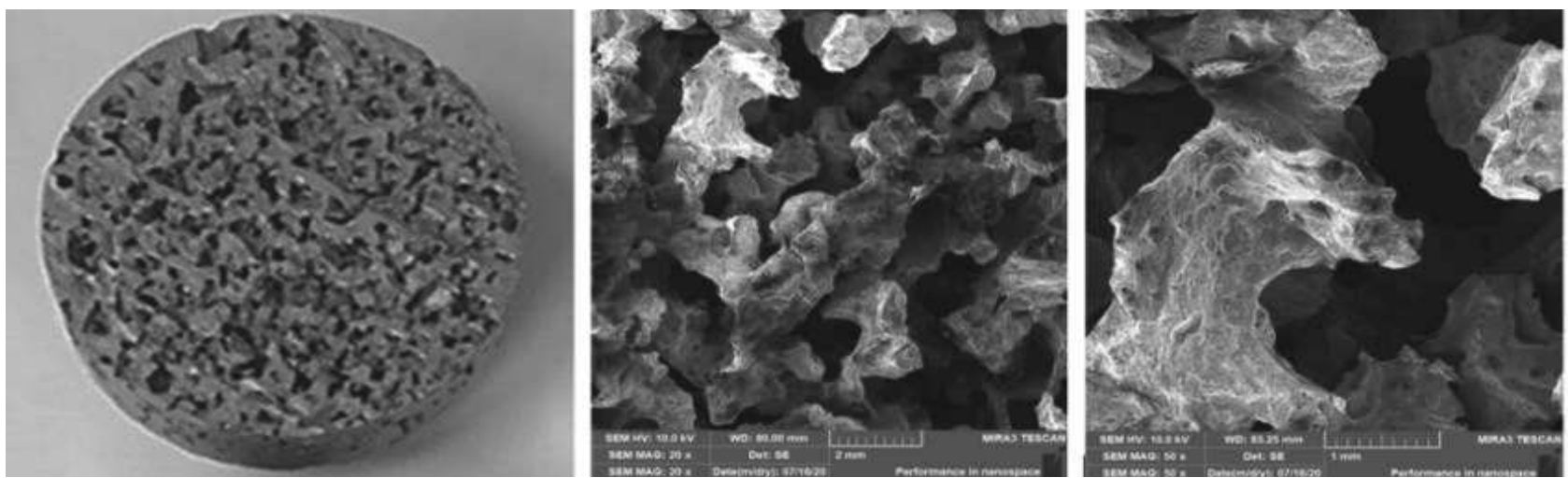

Fig. 8 View of the structure of sample porous material AlSi12 alloy, sample 3

3.3 Monitoring of mechanical properties of selected porous aluminium materials from AlSi12 alloy

The compressive strength of the produced samples was monitored on a TIRA Test tearing machine as is illustrated in Fig. 9,(left). This test was applied to the sample No. 1 and No. 2, i.e. using a sodium chloride particle size of 8 to $10 \mathrm{~mm}$ and 5 to $7 \mathrm{~mm}$.

During the compressive strength test, the effect of porosity, resp. influence of cavity size on compressive strength of material was investigated. Figure 10 shows dependences of stress - strain for a sample with a porosity of 8 to $10 \mathrm{~mm}$ and for a sample with a porosity of 5 to $7 \mathrm{~mm}$.

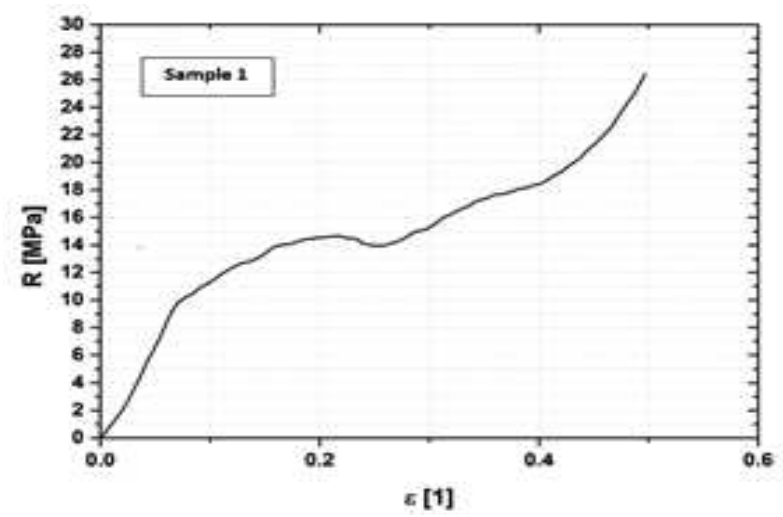

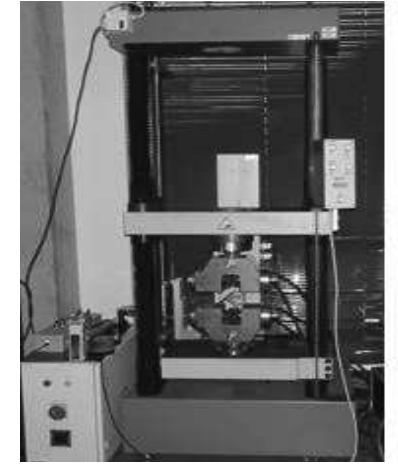

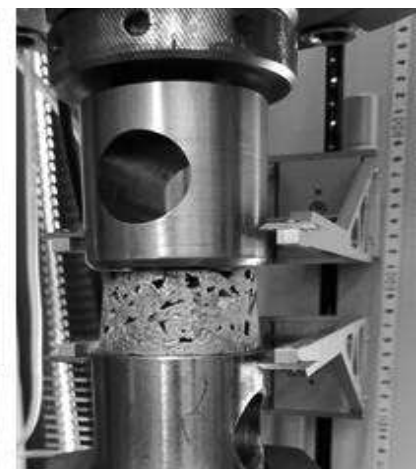

Fig. 9TIR A device Test for measuring the strength of samples, on the left and detail of the pressure test of aluminium porous materials, on the right

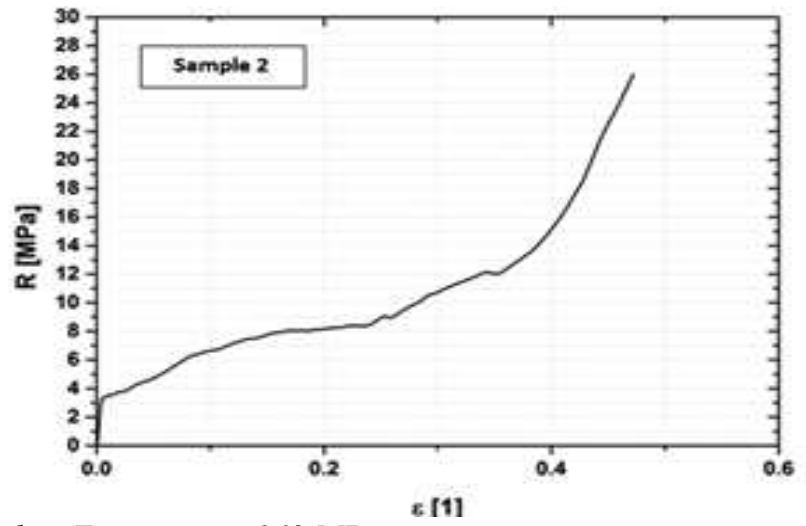

Sample 1 - Young's tensile modulus, $E_{P(\text { AlSi 12)-1 }}=160 \mathrm{MPa}$;

Sample 2 - Young's tensile modulus, $E_{P(\text { AlSi 12)-2 }}=1027 \mathrm{MPa}$;

Fig. 10 Compressive strengths of aluminum porous materials from AlSi12 alloy, samples 1 and 2 


\section{Conclusion}

The property values of these porous aluminium materials are not very well published. These materials are used mainly in the function of filters. The obtained results of the produced samples confirmed that porous aluminium materials of simple geometric shapes can be successfully used. In fact during the production process, the use of $50 \%$ by volume of sodium chloride and $50 \%$ by volume of aluminium alloy AlSi 12 was peffered.with the possibility of application of sodium chloride particle with the specific size of 8 to $10 \mathrm{~mm}$; 5 to $7 \mathrm{~mm}$ and 3 to $5 \mathrm{~mm}$. At the same time, samples of porous aluminium material were obtained from an alloy with a porosity of 59 to $64 \%$ and a density of about 950 to $1085 \mathrm{~kg} \cdot \mathrm{m}^{-3}$. Young's modulus of same 1 is about $160 \mathrm{MPa}$. The calculation of the value of $\mathrm{E}$ according to equation (5) is $958 \mathrm{MPa}$, which is almost 6 times higher than the value obtained from the test at a pressure of $160 \mathrm{MPa}$. Using sodium chloride particles with a size of 5 to $7 \mathrm{~mm}$ (sample 2), the value of the Young's modulus of elasticity was calculated from the stress-strain curve, which is $1027 \mathrm{MPa}$. The value of the Young's modulus of elasticity calculated according to equation (5) is $1055 \mathrm{MPa}$. As can be seen from Fig. 10, the stress-strain curve of the porous aluminium material corresponds to the mild steel curve. The curve consists of three areas. The first area is the steep stress curve. Walls around the cavities are quite strong and contribute to a small deformation as can be clearly seen from Fig. 10 (right). In the second area, the stress-strain curve is slower, less steep with large strain. The lower strength of the walls around the cavities already contributed to this deformation. With increasing stress, cell walls are gradually deformed and collapsed and gradually the porous material begins to be compact (collect). In the third area, the already compact material is further deformed, so the stress rises steeper until its integrity is broken. Our compressive strength results confirmed the general assumption that the larger sodium chloride particles created larger cavities in the material and therefore the greater porosity. Thus, the porous material exhibits lower compressive strength.

\section{Acknowledgement}

The work has been financially supported by the project "Hybrid materials for hierarchical structures", research goal: Composite materials and structures, research program: Materials and structures on the metal basis, reg. no. CZ.02.1./0.0/0.0/16_019/0000843 provided by the European Union and the Czech government.

\section{References}

[1] De MELleR, M. A. (1926). Produit Métallique Pour L'obtention D'objets Laminés,
Moulés Ou Autres, Et Procédés Pour Sa Fabrication. French Patent 615, 147.

[2] BANHART, J. (2000). Manufacturing Routes for Metallic Foams. Journal of Minerals, Metals and Material Society. Vol. 52, No. 12, pp. 22 - 27.

[3] BANHART, J. (2001). Manufacture, characterisation and application of cellular metals and melt Al foams. Progress in Materials Science 46, pp. 559-632.

[4] SURACE, L. DE PHILIPS, L. A. C. LUDOVICO, A. D. BOGHETISCH, G. (2009). Influence of Processing an aluminium foam produced by space holder technique. $M a$ terials and Design 30, pp. 1878-1885.

[5] LUNA, E. M. E. at al. (2014). Casting Protocols for the production of open cell aluminium foams by the replication Technique and the Effect on porosity. Journal of Visualized Experiments. (94), e52568. www.jove.com.

[6] LUNA, E. M. E. (2016). Investigation of Porous Metals as Improved Efficing Regeneration. [Doctoral thesis], The University of Sheffield - Faculty of Engineering, March.

[7] ASHBY, M.F. et al. (2000). Metal Foams: A Design Guide. Ed. Betterwort-Heinemann.

[8] CONDE, Y. DESPOIS, J.F. GOODALL, R. MARMOTTANT, A. SALVO, L. SAN MARCHI C. and A. MORTENSEN. (2006). Replication processing of highly porous materials. Advanced Engineering Materi- als, Vol. 8, No. 9, pp. 795-803.

[9] GOODALL, R. (2013). Chapter 10 - Porous Metals: Foams and Sponges, In I.T. Chang and Y.Y. Zhao eds. Advances in powder metallurgy: Properties, processing and applications, Cambridge: Woodhead Publishing Limited, pp. 273307.

[10] ASHBY, M. F. EVANS, A. G. FLECK, N.A. GIBSON, L.J. HUTCHINSON J.W. and H.N.G. WADLEY. (2000). Metal Foams: A Design Guide, Boston: Butterworth Heinemann, pp. 1-39.

[11] CZYZEWSKI, A. (2011). Nature inspires new methods of making porous materials [Online]. Available: $\quad$ bttp://wnw theengineer.co.nk/civil/ news/nature-inspires-new-methods-of-making-porous materials / 1009543.article. (August 1).

[12] ROUQUEROL, J. ANVIR, D. FAIRBRIDGE, C. W. EVERETT, D. H. HAYNES, J. H. PERNICONE, N. RAMSAY, J. D. F. SING, K. S. W. and K. K. UNGER. 
(1994). Recommendations for the characterization of porous solids. Pure \& Applied Chemistry, Vol. 66, No. 8, pp. 1739-1758.

[13] LIU, P. HU, B. YU, A. LIANG, K. and S. GU. (2001). Development in applications of porous metals. Trans. Nonferrous Met. Soc. China, Vol. 11, No. 5, pp. 629-638.

[14] MORENO, F.G. (2016). Commercial Application of metal Foams: Their properties and production. Materials, 9. 85, pp. $1-27$.

[15] ARrUA, R. D. STRUMIA, M. C. and C. I. ALVAREZ-IGARZABAL. (2009). Macroporous monolithicpolymers: Preparation and applications. MDPI Materials. Vol. 2, No. 4, , pp. 2429-2466.

[16] NANSAARNG, S. and S. SOPHA. (2008). A Synthesis of Aluminium Foams from Ingot by Compessing Meth Method. In. Progresing of the 1 st WSEAS International Conference on Materials science (MATERIALS' 08). ISSN 1790-2769, pp. 130-133.

[17] AIDA, S. F. HIJRAH, M. N. AMIRAH, A.H. ZUHAILAWATI, H. and A.S. ANASYIDA. (2016). Effect of $\mathrm{NaCl}$ as a space holder in producing open cell A356 aluminium foam by gravity die casting process, Procedia Chemistry 19, pp. $234-240$.

[18] HUSSAIN, Z. and N. S. A. SUFFIN. (2011). Microstructure and Mechanical Behaviour of Aluminium Foam Produced by Sintering Dissolution Process Using $\mathrm{NaCl}$ Space Holder. Journal of Engineering Science, Vol. 7, pp. 37-49.

[19] BÁEZ-PIMIENTOA, S. HERNÁNDEZROJASB, M.E. and M.E. PALOMARPARDAVÉC. (2015). Processing and characterization of open-cell aluminum foams obtained through infiltration processes. Procedia $M a$ terials Science, No 9, pp. $54-61$.
[20] BAFTI, H. and A. HABIBOLAHZADEH. (2010). Production of aluminium foam by spherical carbamide space holder techniqueprocessing parameters. Material and Design, 31, pp. 4122-4129.

[21] PIMIENTO, S. B. ROJAS, M. E. H. and M. E. P. PARDAVÉ. (2015). Processing and Characterization of Open-cell Aluminum Foams Obtained Through Infiltration Processes. International Congress of Science and Technology of Metallurgy and Materials SAM - CONAMET 2014. Procedia Materials Science, 9, pp. 54-61.

[22] HASSANI, A. HABIBOLAHZADEH, A. and H. BAFTI. (2012). Materials at Design. Vol. 40, Septem- ber, pp. 510-515.

[23] SVOBODOVÁ, J. LUNÁK, M. and M. LATTER. (2019). Analysis of the Increased Iron Content on the Corrosion Resistance of the AlSi7Mg0.3 Alloy Casting. Manufacturing Technolgy, Vol. 19. No. 6 pp. 10411046, ISSN 1213-2489.

[24] NOVÁ, I. FRAŇA, K. SOBOTKA J. SOLFRONK, P. KOREČEK, D, and I. NOVÁKOVÁ (2019). Production of porous Aluminium Using Sodium Chloride. Manufacturing Technolgy, Vol. 19. No. 5 pp. 817-822, ISSN 1213-2489.

[25] SCHINDLER, A and M. SCHÖNEICH (2016). Presentation of the results of the analysis of sodium chloride - Investigation of Alkali Salts with the STA 449 F5 Jupiter $\AA$. Technical materials from NETZSCH Gerätebau $\mathrm{GmbH}$, Selb - Germany.

[26] JERZ, J. (1995). Foamed Aluminium and Aluminium Alloys. Prepared by Powder Metalurgy. Ph.D. thesis, TU Vienna. 